Educational Administration Quarterly

Vol. 21, No. 1 (Winter 1985) 95-117

\title{
Benno Sander
}

Thomas Wiggins

\section{Cultural Context of Administrative Theory: In Consideration of a Multidimensional Paradigm}

The continuing perceived complexity of educational systems and the current status of organizational and administrative theory suggest the need for a renewed theory-building effort in the field of educational administration. It is in this sense that this article presents a multidimensional paradigm for the study of educational administration in the Americas. The paradigm is an attempt to explicate the domains of the cultural, pedagogical, political, and economic influences on educational administration. It views culture in context and is based on the knowledge foundations contributing to the field of educational administration.

Benno Sander is Professor of Education in the School of Education at the University of Brasilia (Brasilia, DF) and in the School of Education at the Universidade Federal Fluminense (Niteroi, Rio de Janeiro, Brazil). Thomas Wiggins is Professor of Education and Human Relations at the University of Oklahoma.

\footnotetext{
An ar $\mathrm{n}$ analysis of the evolution of 20th century administrative thought, coupled with a survey of recent research in the field of educational administration, reveals a restlessness regarding the status of administrative theory. Thus, the trend to dwell with some concern upon theory building is both understandable and justified. Further justification comes as a consequence of the growth and complexity of educational systems and as a result of the current social awareness of the nature of education in the Americas.
} 
The primary objective of this article is to review some of the efforts that have been made to construct scientific knowledge in the field of educational administration. The authors of the article further seek to define a heuristic paradigm for the study of educational administration in the Americas. The paradigm as such is founded on knowledge developed historically and represents an attempt to arrive at a theoretical synthesis of the American experience in the international context. However, in light of this historical view, this paradigm is also developed to respond to current demands and necessities of American education. Finally, this effort is based on the thesis that educational administration is a professional field of study and on an awareness of the necessity of conceiving a new and integrating theory of the professional practice of educational administration. ${ }^{1}$

\section{HISTORICAL PERSPECTIVE OF ADMINISTRATIVE THEORY}

From a historical point of view, administrative theory of the current century developed from three schools of thought: the classical, the psychosocial, and the contemporary. The classical thesis was expounded at the beginning of this century at the time of the consolidation of the industrial revolution. Three major movements were largely responsible for classical theory: scientific management (Taylor), general management (Fayol), and bureaucratic management (Weber). ${ }^{2}$ The protagonists of the classical school conceived of the organization as a mechanical and rational system in which management was founded upon the criterion of economic efficiency.

The psychosocial antithesis developed in a historical sense from the time of the Great Depression in the United States that also affected the world at large at the end of the decade of the 1920s. The movements responsible for this development were those of the emphasis on human relations (Mayo, and Roethlisberger and Dickson) and the focus on administrative behavior (Barnard and Simon). ${ }^{3}$ The protagonists of the psychosocial school conceived of the organization as an organic and natural system. Management was perceived as being concerned with the functional integration of its component elements in the light of the criteria of institutional effectiveness and economic efficiency.

Following World War II, developments in the 1950s led to the contemporary synthesis, the adherents of which attempted to supplant the previous schools of thought on the basis of the criterion of political responsiveness. Special attention was attributed to situational variables of the external environment that affect the organization. In the 
development of the contemporary school, there were different, but parallel, lines of thought. Examples of these would be the organizational development notions of Bennis, the development administration of Heady and his associates, the administrative ecology of Riggs, the institutional development of Esman and Blaise, the contingency theory of Lawrence and Lorsch, and the management science of Drucker and others. ${ }^{4}$

Today, alongside the neoclassical approach of the managerial sciences, there are also not as yet consolidated critical theories based on phenomenology, existentialism, and dialectics. Action approaches that utilize cultural context as the key element in the orientation of administrative acts and facts are further beginning to attract attention. ${ }^{5}$ This recent attention to critical theory and new theoretical perspectives in the field of administration is appearing in the midst of inter-American economic and political instability that marked the end of the 1970s and the early years of the current decade.

\section{ADMINISTRATIVE THOUGHT IN LATIN AMERICAN EDUCATION}

In Latin America, public administration and educational administration have similarly followed an evolution that had also taken place in Europe and the United States. ${ }^{6}$ Latin America initially subscribed to the juridical approach that was essentially normative in nature and closely tied to the tradition of Roman administrative law that characterized public and educational administration throughout all of colonial history. Following that era, the countries of Latin America adopted the business approach beginning in the 1930s. This approach was based on the principles of the classical school of administration as defended by Taylor, Fayol, and Weber. During that period and following the theoretical steps of those in Europe and the United States, Latin-American scholars and practitioners thus adopted the standard of economic efficiency. This brought about less concern with the cultural and political aspects of administration. Following World War II and a period of rising prestige of the behavioral sciences, public and educational administration in Latin America began to come under the influence of the psychosocial school of North American administration. The behavioral approach was in turn adopted, giving primary attention to effectiveness in the achievement of institutional objectives. In recent decades, a contemporary synthesis has also become evident in Latin America through the increasing utilization of the social sciences in public and educational administration. In this sense, the technical and 
instrumental criteria of efficiency and effectiveness of traditional administration are giving way to the political criterion of responsiveness. Finally, under the influence of anthropological and political factors, current theoretical developments reveal an emphasis on relevance as the criterion on which the concepts of efficiency, effectiveness, and responsiveness of public and educational administration in Latin America are analyzed.

\section{FOUR PARADIGMS OF EDUCATIONAL ADMINISTRATION}

On the basis of the historical perspective of administrative theory described above and its evolution in the Americas, it is possible to define four different paradigms of educational administration: (1) administration for efficiency, (2) administration for effectiveness, (3) administration for responsiveness, and (4) administration for relevance. These four paradigms are defined using the four criteria that have historically been adopted to evaluate and guide the performance of administrative acts: efficiency, effectiveness, responsiveness, and relevance. To define the theoretical essence of each of the paradigms, one should first consider the nature of the different criteria of administrative performance. In itself, this is potentially confusing, particularly as one must cross cultural and language boundaries. Specialized literature on the matter is marked by generalized terminological and semantic confusion. For example, it is common to confuse efficiency with effectiveness, effectiveness with responsiveness, and responsiveness with relevance. Dictionaries of renown affirm that effective is a synonym of efficient at the same time they state that responsive is equivalent to effective. Translators from English to Latin-origin languages fail to translate effectiveness by eficácia, and translate it by efetividade in Portuguese or efectividad in Spanish. ${ }^{7}$ Even the protagonists of the theories of administration themselves are not in full agreement on this matter. There is divergence with respect to the meanings of efficiency and effectiveness between such classical authors as Taylor, Emerson, and Callahan ${ }^{8}$ and behaviorists such as Barnard, Simon, and Getzels. ${ }^{9}$ In their turn, the contemporary authors do not provide clear indications as to the difference between the concepts of responsiveness and relevance in their theories of administration.

Conceptual uncertainties nevertheless demand an effort to attain more specific definitions of administrative criteria adopted in educational administration in order to enhance their utilization in both empirical and analytical settings. Definitions are particularly necessary 
that characterize the nature of the activities of educational administrators in daily practice.

\section{Administration for Efficiency}

Efficiency (from the Latin efficientia: action, strength, virtue of producing) is the administrative criterion that reveals the capacity to produce the maximum of outcomes with the minimum of resources, energy, and time. In the history of administrative thought, the concept of efficiency is associated with that of economic rationality. It is concerned with seeking the means and procedures that are most suitable for attaining specific results and goals, independent of their human and political content or of their ethical nature.

The supreme value of efficiency is productivity, i.e., "efficiency implies proven capability based on productiveness in operation and especially stresses ability to perform well and economically." ${ }^{10}$ Inherent in this performance is technical expertness as measured in terms of the mastery of know-how and maximization of the use of time, energy, material, and other resources. In this sense, the efficient worker is the one who produces the maximum with minimum waste, cost, and effort or, in other words, the one that achieves a high input/output ratio in production activities.

The concept of efficiency arises in the economic and rationalist context of the industrial revolution and becomes the central criterion of the classical literature on administration as elaborated by Fayol, Weber, Taylor, and their associates. The efficiency of Fayol is reflected in the functionalism of his universalistic model. Weber conceived of the rationalistic bureaucracy as the ideal of technical efficiency. Taylor's notions on efficiency had particularly strong impact and were later reinterpreted and improved by Emerson, whose work The Twelve Principles of Efficiency is a classic in the history of administrative thought. ${ }^{11}$ Strongly influenced by the Protestant Ethic, Emerson's approach was clearly economic in nature, for it stated that productivity and prosperity are not consequences of abundance, but rather the result of ". . . ambition, the desire for success and wealth."

Classical administration provided the frame of reference for the development of industrial psychology, which tends towards the study of the "psychological man" alongside the "economic man" of Taylor. Allied to the "mechanical efficiency" of the engineers, industrial psychology, founded at the start of the 20th century by Munsterberg, would give attention to the study of "human efficiency" with the same objective of increasing productivity. ${ }^{13}$ During the early decades of the 
20th century, the influence of psychology was to become even more accentuated in organizational theory to the point that it finally assumed a primary role in the human relations movement of the psychosocial era.

The characteristics inherent in the concept of efficiency in administrative thought are quite useful in that they supply elements used in defining efficiency as a criterion of the economic performance of educational administration. Therefore, the efficiency of educational administration can be defined as the result of extrinsic instrumental performance of an economic nature as measured in terms of the administrative capacity to attain a high degree of productivity.

\section{Administration for Effectiveness}

Effectiveness represents the capacity or potential to attain proposed results. In the history of administrative thought, the concept of effectiveness developed out of the interest in behaviorism in the psychosocial school that consolidated at the outbreak of the Great Depression towards the end of the 1920s. After World War II, effectiveness also became a fundamental criterion of the neoclassicists, who conceived of administration by objectives under the leadership of Drucker, Odiorne, and Humble. ${ }^{14}$ The central concern of those who defend effectiveness as a criterion of administration is the attainment of proposed objectives. In the specific case of the educational system, the effectiveness of administration in this sense is essentially concerned with the attainment of educational objectives, and it is closely related to the pedagogical aspects of the educational system.

Expounding on his concept of organization as a "cooperative system," it was Barnard who distinguished between effectiveness and efficiency. In his line of thought, effectiveness referred to the level of administrative performance in the attainment of institutional objectives, and efficiency was defined in terms of the degree of satisfaction in terms of personal motivations. ${ }^{15}$ In this sense, cooperative efforts are effective when the objective is attained. To Barnard, effectiveness was the major criterion in such a way that the efficiency of individuals was nourished on the basis of effective attainment of the organizational objectives. Therefore, to those who propounded the psychosocial school of administration, the concept of effectiveness took precedence over efficiency.

Some authors distinguish between internal effectiveness and external effectiveness on the basis of the intrinsic or extrinsic nature of the desired objectives. The concept of effectiveness of educational administration is restricted here to the intrinsic aspects of the educa- 
tional system and, thus, is concerned with the attainment of educational objectives. The concern with the strategic actions taken to attain the extrinsic objectives of the educational system that are of a political nature follows the criterion of responsiveness, a notion that will be developed next.

The effectiveness of educational administration is, therefore, conceived in this perspective in terms of the criterion of intrinsic and instrumental performance of a pedagogical nature as measured in terms of the administrative capacity to attain proposed educational objectives. Based on the supposition that, within an educational system the attainment of educational objectives takes precedence over the utilitarian aspects of an economic nature, there exists a priority ordering of effectiveness over efficiency. In other words, effectiveness is an intrinsic criterion of the educational system while efficiency is an extrinsic criterion.

\section{Administration for Responsiveness}

The concept of responsiveness arose in contemporary administration through efforts to go beyond the concepts of efficiency and effectiveness. The Portuguese and Spanish terms for responsiveness, respectively efetividade and efectividad (from the Latin verb efficere: to fulfill, to carry out, to solidify), signify something real, something true, that causes a concrete effect. Frequently, the concept of efetividade or efectividad has been confused with that of eficácia, the Portuguese and Spanish term for effectiveness that is a synonym of efficacy and efficacious. ${ }^{16}$ The English term responsiveness, as it arose in the theory of contemporary administrative theory, reflects the capacity of meeting the politically expressed demands of the external community. In other words, responsiveness is the criterion of performance that measures the capacity to produce the solution or response desired by the participants of the larger community. In certain aspects, the concept of responsiveness is associated with that of social responsibility or accountability, according to which administration is obligated to answer for its own acts on the basis of the concerns and priorities of the community. ${ }^{17}$

Responsiveness is the central criterion of developmental adminitration. It is a theoretical construct associated with the comparative emphasis of public administration that arose following World War II as viewed in the broader context of political theory. The fundamental concern in responsiveness is that of furthering socioeconomic development and improved standards of living. It is in this sense that responsiveness attempts to go beyond the limitations of the technical 
criteria of efficiency and effectiveness: "It refers to more ample objectives of equitableness and socioeconomic development." 18

Applying the concepts of effectiveness and responsiveness to educational administration, one is able to draw associations between effectiveness and the attainment of educational objectives and responsiveness and the attainment of social objectives. The traditional emphasis on the technical criteria of efficiency and effectiveness was associated to the intended scientific neutrality of educational administration. This, however, is a neutrality that is incompatible with administration founded on the criterion of responsiveness.

The concept of responsiveness presupposes a real and true commitment to the social objectives and political demands of the community, including its educational system. The materialization of this commitment demands an even greater concrete obligation on the part of the administration to the life of the community through a philosophy of solidarity and a participatory methodology. ${ }^{19}$ The greater the degree of solidaristic participation on the part of all the members of the community, the greater will be the responsiveness and the political capacity to respond concretely and immediately to needs and aspirations of a social nature. To describe the degree of the political commitment of educational administration, some authors employ the concept of relevance instead of responsiveness. ${ }^{20}$ However, for the purposes of this discussion, responsiveness is conceived within a political perspective and relevance is reserved for use within a cultural perspective as will be developed in the next section.

The interest and concern about responsiveness, as a criterion of the political performance of administration, reveal a capacity of responding and acting based on the social and political demands of the community, including its educational system. In this sense, the degree of responsiveness of educational administration can be measured in terms of its capacity to act in a genuine manner in response to social necessities and political demands. The fundamental and substantive importance of these social necessities and political demands gives responsiveness a position of conceptual priority in relation to effectiveness and efficiency.

Responsiveness manifested through participatory methodology has the potential effect of uncoupling otherwise tight organizations. Open systems, characterized as loosely coupled systems, ${ }^{21}$ in reality contain elements that range from interrelated to reasonably autonomous components. Weick, and Pfeffer and Salancik, view open systems with loose coupling as adaptive, facilitating enactment, and responsive. ${ }^{22}$ 


\section{Administration for Relevance}

The concept of relevance (from the Latin verb relevare: to raise, emphasize, give value to) is the raison d'etre of administration that is oriented to the improved quality of human life. Relevant is that which is truly important, that which has value. Relevance and value are synonyms which make up "... the criteria employed in selecting the goals of behavior. $" 23$ However, one must then ask: value and importance to whom? The value is ideally accrued to those individuals and groups who participate in the educational system and community as a whole, seeking to develop a qualitatively improving nature of human life. Relevance and value are the bonding agents between the functions of educational administration and the quality of the human experience.

The concept of quality of collective human life has a culturally specific meaning. In other words, the quality of human life is a cultural peculiarity of each human grouping and, as such, is defined on the basis of the perceptions and interpretations of the participants in that group. It is precisely culture, as the historical and ecological characterization of the group, that should provide the organizational frame of reference for collective participation in the definition of relevance and in the furthering of the quality of associated human life. Relevance suggests the idea of pertinence and value or the bond of a relationship with something or someone. In this specific case: "Relevance implies a traceable, significant, logical connection ..."24 between two realities. On the one hand, there is administration, and on the other, there is the quality of the human life of the participants defined according to their own existential choices. In this sense, relevance is a criterion of performance measured in terms of significance, value, and importance. This includes the pertinence of administrative acts and facts for the life of the participants in a larger human group and its educational system.

In adopting relevance as a fundamental criterion, one must appraise educational administration in terms of the meanings and consequences of activities for the improvement of the quality of human life in society. The perception and interpretation of these meanings and consequences in this sense is only possible through an administrative theory conceived on the basis of real experience. This theoretical conceptualization is directly founded upon the participative posture of those responsible for the administration of the educational system. The more participatory, solidaristic, and democratic the administrative process, the greater will be its chances of being relevant to individuals and groups and the greater 
will be its possibilities of explaining and furthering the quality of collective human life. ${ }^{25}$

The distinction between relevance and responsiveness is not always clear in the specialized literature. Wittman's concept of relevance, for example, overlaps the previously defined concept of responsiveness. Based on the supposition that "educational administration is essentially a political act, ${ }^{26} \mathrm{Wittman}$ adopts an approach that is more political than cultural and, as such, is concerned primarily with the meaning and impact of the activities of educational administration on society. The concept of relevance as set forth here gives primacy to the cultural considerations of educational administration. It concerns itself primarily with the conception of the human being as an individual and with the concept of the quality of collective human life as the basis for political action in society. This principle has the purpose of forewarning the educational administrator against the dangers of extrinsic activism devoid of cultural contextual concerns and intrinsic considerations of the human being living in society. Nevertheless, one should emphasize that the cultural dimension is also present in the work of Wittman such as when he refers to the commitment of educational administration with Brazilian culture, "intersubjectivity," and the "construction of a more just, more solidarist and more human Brazilian society." 27 It is the intention here to associate the concept of responsiveness with the political dimension of educational administration and the concept of relevance with the cultural dimension. Wittman, however, unifies the concepts of responsiveness and relevance into a single, more general political dimension. This discussion demonstrates the close substantive complementarity of the criteria of relevance and responsiveness in the practice of educational administration since, in reality, anthropological man and political man are one and the same being. Anthropological man becomes political man when he is involved in a coherent manner in real society. In other words, human relevance takes on form in society through political responsiveness.

\section{A MULTIDIMENSIONAL PARADIGM OF EDUCATIONAL ADMINISTRATION}

Although the four paradigms of administration correspond to historically distinct periods, they often converge in a practical sense. This convergence of paradigms is confirmed in the Western Hemisphere by the specialized literature on the topic. A case in point is that of Brazil, where the specialized literature shows that educational systems and 
institutions of a strictly business nature now exist in which administration is governed by economic efficiency as a predominant criterion with other criteria complementing the primary one. It is in this sense that, when referring to university administration, Brito proposed a business solution based on organizational efficiency. ${ }^{28}$ Other educational institutions and systems are more concerned with their political role in the community and, for this reason, their administration is primarily based upon the criterion of responsiveness. Within this context, one should also take note of the work of Arroyo and Wittman, who conceived of educational administration as a fundamentally political act. ${ }^{29}$ There are other educational institutions and systems in which administration is guided principally by effectiveness in the attainment of pedagogical objectives. Yet other educational institutions and systems are concerned fundamentally with the human being as an individual and social entity. For this reason, these latter systems and institutions adopt relevance as the criterion of their administration. In the last decade, the work of Rezende and his associates has made a contribution to the study of the anthropological and pedagogical foundations of educational administration. $^{30}$

The diversity of these analytical principles suggests a complex educational reality within a social environment that is in a state of permanent change and that demands a constant renewal of administrative solutions and alternatives. However, the definition of appropriate systems of studying and implementing educational administration in the Americas within the context of the educational necessities and aspirations of society is an intellectual task of immense proportions. In methodological terms, it is possible to visualize two different potential solutions in this regard. The first consists of conceiving of the four paradigms as four parallel paths to be utilized by educational scholars and practitioners. The option for one of the various paths in this sense is made on the basis of the nature of the institution and as a result of the perceptions and interpretations of the educational realities and administrative phenomena on the part of those responsible for the operation of the educational system. This approach is possible in a pluralistic society in which theoretical pluralism encourages scientific progress through the development of competitive, convergent, or contrary paradigms that tend to supersede one another. ${ }^{31}$

However, the four paradigms are heuristic elaborations and, as such, may not exist in pure form in real life. In this perspective, there arises a second solution that concerns itself with the conceptualization of a new paradigm through a theoretical synthesis of practice in educational 
administration. In fact, this integrating synthesis would constitute a global paradigm, based on the analysis of the similarities and contradictions among the four paradigms. In keeping with this approach, instead of defining administrative phenomena in terms of parallel paradigms, they would be conceived as interrelated aspects or parts of a holistic or multidimensional paradigm.

It is in this sense that the four specific paradigms can be synthesized into a global paradigm defined as the multidimensional paradigm of educational administration. Such a paradigm would be composed of four interacting dimensions: the economic, pedagogical, political, and cultural, each of which corresponds to a specific criterion of administration: efficiency, effectiveness, responsiveness, and relevance, respectively. The conceptualization of the multidimensional paradigm of educational administration is, further, based on three fundamental assumptions: first, that educational phenomena and administrative facts are interrelated aspectsof a multidimensional paradigm with areas of emphasis that are sometimes complementary; second, that in the educational system there are intrinsic dimensions of a cultural and pedagogical nature that exist alongside extrinsic dimensions of a political and economic nature; and, third, that the human being as an individual and social entity involved politically in society constitutes the raison-d'etre of the educational system. It is this sociopolitical conception of the human being that defines the nature and utilization of the multidimensional paradigm of educational administration as heuristic. These concepts, as shown in Figure 1, are reflected in a system in which two substantive dimensions and two instrumental dimensions are placed in contact with two intrinsic dimensions and two extrinsic dimensions.

The conceptualization of the multidimensional paradigm of educational administration is based on a philosophical definition in which the instrumental dimension is regulated by the substantive dimension. At the intrinsic level, the latter is directly related to the fundamental values and aspirations of human beings as individuals and social entities. (The individual is considered as historically situated within a specific cultural environment.) At the extrinsic level, the substantive dimension is directly related to the attainment of the political ends and objectives of society. This philosophical orientation does not combine with systems of social and political organization devoid of regulations that proclaim individualistic independence without social commitment. In the perspective of this paradigm, freedom of choice on the part of the human being implies adhesion and social responsibility. ${ }^{32}$ 


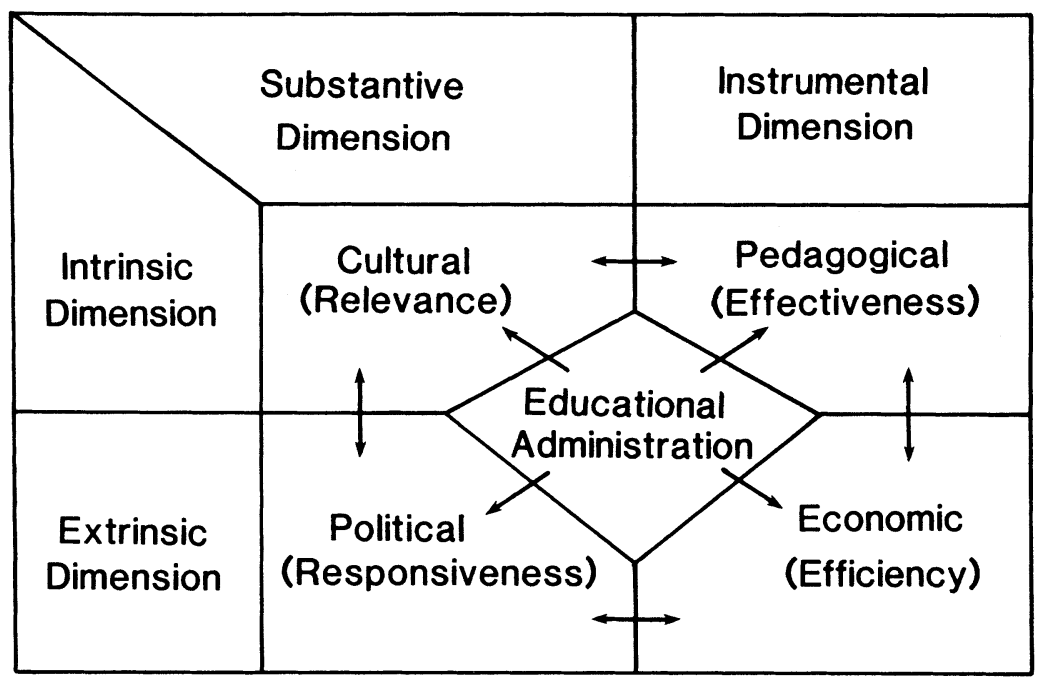

Figure 1: A Multidimensional Paradigm of Educational Administration

Through the logic of the multidimensional paradigm, one can reject administrative solutions based on totalitarianism that inhibits freedom of action. The paradigm is based on the identification of those dimensions that make fulfillment of the human being possible, both as an individual and as a social entity. In the terms of the multidimensional paradigm, educational administrators are guided by substantive and ethical concepts of general validity such as liberty and equality that, in turn, create the organizational framework for collective participation in the furthering of a qualitative form of associated human life. ${ }^{33}$

\section{The Economic Dimension}

The economic dimension of the educational system involves financial and material resources, structures, bureaucratic norms, and mechanisms of coordination and communication. In this dimension, educational administration involves the distribution and control of resources, the organization of the institution in structural terms, the determination of roles and responsibilities, the distribution of work, the determination of how the work is to be carried out and by what type of incumbents, and the establishment of norms of action. The defining criterion of the 
economic dimension is efficiency in the utilization of the technological resources and instruments under the rule of economic logic. In this sense, the concepts of efficiency and economic rationality govern the different activities of educational administration. This includes budgetary preparation and implementation, planning and allocation of physical facilities, the preparation of schedules, curriculum organization, selection of personnel, and the supply of equipment and technological material. Administration is efficient to the extent that it is capable of optimizing input-utilization of the financial resources and the material and technological instruments of the educational system.

The study of the economic dimension of the educational system is founded on economics, business management, accounting, organization and methods, and technology. All of these areas are primarily concerned with the efficiency of the system and, consequently, suffer the influence of the rational and utilitarian logic of the world of business. For this reason, observations will be restricted to economics and secondarily to contributions of the other related areas.

Today, there exists a vast amount of literature on the economic context in which the educational sector operates and on its implications for the study and practice of educational administration. The economics of education has developed rapidly in recent decades and has concentrated on the analysis of the economic value of education. ${ }^{34}$ It also attends to the economic aspects of educational systems, such as the external productivity and internal effectiveness.

Traditionally, the economics of education has considered the educational system under the discipline of economics, the functional logic of which has sometimes been transformed into the paradigm responsible for the modeling of the academic process and human life itself. Within this context, in recent decades, many aspects of the socioeconomic orientation of developmental administration that is common in the public sector, in which the concept of planning has been particularly emphasized, have been incorporated into educational administration. Even though economists of many and varied currents of thought, ranging from the classical to the modern, have conceptualized education as consumption, the emphasis attributed to the economic value of education and to the investment in human beings ${ }^{35}$ reflects a philosophy that alters the intrinsic value of education and of human life itself. In the last decade, however, there has been a gradual process of moving away from the strictly economic aspects to the social and political aspects of educational planning. ${ }^{36}$ 


\section{The Pedagogical Dimension}

The pedagogical dimension of educational administration refers to the principles and educational scenarios and techniques that are intrinsically committed to the effective attainment of the objectives of the educational system. In recent decades, the pedagogical dimension of educational administration has been subjected to a process of atrophy as a consequence of the generalized emphasis on considering the educational system in terms of economic and technological development.

The predominance of the role of economy in education has conditioned administrative actions in the field of education, and as a result, education has been transformed into a business-like act, based upon economic logic. As a reaction to this situation, in some academic environments there has been increased concern with administration as a pedagogical act to use the expression of Rezende and his associates. ${ }^{37}$ The defenders of the pedagogical dimension have no intention of eliminating consideration of the economic aspects of administration, nor do they intend to separate education from the technological development of a nation. Much to the contrary, their concern is that of attributing to administration the responsibility for conceiving of spaces, methods, and techniques that are capable of preserving educational purposes and the objectives of the educational system in their efforts to adequately fulfill their economic, cultural, and political role in society. In fact, the pedagogical dimension of educational administration is related to all aspects of the educational system. It has the objective of providing appropriate conditions of permanent education to those persons who participate in the educational system. In the words of Chagas, it is intended through this notion to avoid the problems "... that the instrumental absorbs the essential and ... the act of administering tends to overshadow or eliminate the act of educating." 38 This dimension is closely related to the other dimensions of the paradigm. In this sense, administration will be increasingly effective to the extent that it is successful in attaining educational objectives broadly conceived.

The study of the pedagogical dimension of educational administration is based upon a wide array of disciplinary contributions ranging from philosophy to cybernetics. Philosophy and political science are the central disciplines, since the educational system-as more than a pedagogical plan - should be founded upon a philosophy and a political strategy, and should reflect the historical moment and the social reality. 
Only through the alliance of political philosophy and pedagogy is one able to coherently explain the educational theory and practice in use in a community. Aside from this, pedagogy is based upon biology, psychology, and anthropology as well as other disciplines. Finally, in the elaboration and utilization of educational technology, pedagogy resorts to information, retrieval cybernetics, and other technological concerns.

\section{The Political Dimension}

The political dimension involves the strategies of concrete action of the participants in the educational system in society. The importance of the political dimension is rooted in the specific responsibilities of the educational system with respect to society. Its importance also resides in the fact that the educational system evolves in the context of the varied conditional circumstances of the environment. This importance is further accentuated to the extent that the evidence demonstrates that the aspects of educational administration that are associated with the anthropological and pedagogical dimension are influenced by powerful external variables. If educational administrators are not capable of adequately balancing the powerful relationship of the cultural and pedagogical elements with the external environment, they run the risk of closing the educational system in upon itself. The result of this would be the loss of political power in the community. Within this dimension, those in educational administration should seek responsiveness, a criterion that is essentially political and according to which the educational system is called upon to meet the necessities and social demands of the community to which it pertains. In this sense, the greater the strategic capacity to meet the social necessities and political demands of the community in which the educational system functions, the more effective will be the administration of education.

To study and understand the political dimension of educational administration, fundamental principles must be sought from political science and political sociology as well as from the contributions of administrative law, public administration, and political and cultural anthropology. The perception of a political scenario in education is of fundamental importance to educational administration. For a long time, it was affirmed that administration was ideologically neutral and, thus, isolated from politics by the fact of its intended instrumental character. However, the classic postulate of the dichotomy between politics and administration has been shown to be inadequate in public 
administration, particularly in the developing nations. As a matter of fact, in this particular case, administration is called upon to perform a highly political role. Consequently, it is in political science that the administrator will seek insight and knowledge for regulating the multiple elements that act on the educational system.

Political sociology, which has as its central theme the analysis of the social bases of power in all sectors of society, is a discipline of pertinence to the study and practice of educational administration. If educational administration is a political process and if political sociology concentrates its attention on the social conditions of the political process, the educational administrator will find a valuable basis for his or her professional activities in the area of political sociology.

Alongside political science and political sociology, public administration has a contribution of particular importance to make to the educational administrator since it has evolved in the political and administrative context of the public sector. Education in the Americas, both governmental and private, is directly or indirectly related to the powers of the State; as such, its administration will only be faithfully expressed if it does not ignore developments in the field of public administration.

The administrative law is a study of the juridical ordering of the organization and activity of the political society through the specific juridical realities that govern the rights and duties of the governmental and private institutions. It is closely associated with the administration of the different sectors of public activity, and as such, provides valuable elements of support to those professionals who dedicate their efforts to the study and practice of administration in the educational sector. In fact, educational legislation and its jurisprudence are elements in the field of administrative law from the doctrinal point of view. Doctrine can be considered as the systematization of laws and juridical principles, whereas the purely legal is that which concerns the existence of laws regulating the educational activities of the state or nation and of society as a whole. This is culturally specific to those settings of concern.

Many themes of educational administration go well beyond the borders of political science, political sociology, public administration, and administrative law and involve culture and society as a whole. In this sense, the cultural context takes on much greater importance, and in this light, those in educational administration must turn their attention to cultural anthropology and political anthropology. These disciplines study the cultural signposts and political aspects of society, respectively, without losing sight of the totality that characterizes the studies of 
general anthropology. Such a global vision of the human being living in society offers an adequate parameter for conceiving a system of educational administration that is prepared to deal with the complex of social relations that flow within the context of a given society according to a code of cultural norms and values, i.e., its cultural context.

\section{The Cultural Dimension}

The cultural dimension covers the philosophical, anthropological, biological, psychological, and sociological values and characteristics of the people who participate in the educational system and in the society in which the system functions. Although the cultural dimension includes many aspects and levels, its basic characteristic is its global perspective that makes it possible for culture to take into account the physical, psychological, anthropological, social, and philosophical aspects of human life. In this dimension, the role of the educational administrator is one of coordinating the action of the persons and groups who participate directly or indirectly in the educational process in the community. Considered also are all of this dimension's characteristics and values in such a way that a qualitative form of human life in society is furthered. For this reason, educational administration is closely related to the beliefs and values, the biological and psychological attributes, the philosophical persuasions, and the social characteristics of the persons and the groups involved in the educational system and the community in which the system functions.

In this cultural dimension, relevance is the basic criterion that guides activity. Efforts are directed to motivate adequately the activities of all of the participants of the educational system and its social environment with the objective of furthering a qualitative form of human life in society. Therefore, administration will be relevant to the extent that it fosters the conditions that make it possible to further the quality of collective human life in society, in the educational system, and in the community in which the system functions.

Aside from anthropology, philosophy and philosophical anthropology, psychology and physical anthropology, and sociology and social anthropology offer theoretical bases for the study and understanding of the cultural dimension of educational administration. Philosophy is the general science of principles, causes, and human values, while anthropology is the comprehensive discipline that studies the nature of the human being, including its biological and cultural characteristics. 
In the vast field of psychology, it is social psychology that assumes special importance since it is the science that studies the individual and the social situation simultaneously on the basis of models that reflect the complexity both of the social stimuli and of individual differences. Of particular importance to educational administration are the writings in social psychology on the capacity and creativity of the human being living in community and the scientific effort made to find answers to the difficult social and personal problems that exist in the educational system and in society as a whole. In reality, educational administration is a process directed by human beings acting and interacting within a complex socio-educational system. In this context, it is the task of administration to establish those conditions that make it possible for human beings to reach fulfillment as individuals and social beings through the development and work of an educational system.

As the discipline that focuses on the models of action and interaction of persons, groups, and organizations in society, sociology is also closely associated to the study and practice of educational administration. The study of organizations, of the relations between and among people, and of human groups has significant implications for the administration of the educational system.

\section{CONCLUSION: ADMINISTRATION AND THE ADMINISTRATOR}

The multidimensional paradigm of educational administration is an attempt to arrive at a theoretical synthesis of the American experience in the field of educational administration. The historical evolution of knowledge in the field of educational administration reflected in the form of four sometimes opposing, sometimes complementary, and certainly overlapping criteria can be conceived in the multidimensional form of a model. The relative emphasis given in any instance to the different dimensions is ultimately based on the philosophical orientation taken, the nature of the phenomena at hand, and the spatial and historical situation in which they occur.

The conceptualization of this specific paradigm is founded on the philosophical definition that attributes to the cultural dimension of education. Since this is only an initial statement of the paradigm and its rationale, it is recognized that there is a need for consideration of the model within the context of the Americas, collectively, and in individual nations. ${ }^{39}$ It is also important to note that the elaboration and refinement of theories and paradigms of educational administration is a 
task performed by human beings, and the models of educational administration cannot go beyond the practitioners who are responsible for utilizing them. This suggests the need for a priority effort toward the study of the administration of American education along the lines prompted by the conceptualization.

According to the notions of the multidimensional paradigm proposed, the selection and preparation of educational administrators should consider four types of competence: economic, pedagogical, political, and cultural. The economic competence of the educational administrator refers to efficiency in optimizing the inflow and utilization of resources and the technical and rational elements for the attainment of the objectives of the educational system. The pedagogical competence of the educational administrator reflects a capacity to formulate educational objectives and prepare effective pedagogical scenarios and means to attain such objectives. The political competence defines the abilities of the educational administrator in perceiving the external environment and its influence on the educational system and its participants. It necessitates a capacity to adopt strategies of concrete action for the responsive satisfaction of the social and political necessities and demands of the community and its educational system. Finally, the cultural competence of the educational administrator includes a demonstrated capacity to conceive of solutions and exercise leadership in the implementation of these solutions under the criterion of relevance. Furthering the qualitative aspects of human life in society makes it possible for the participants in the educational system and in the community as a whole to reach fulfillment.

The preparation of researchers and administrative practitioners on the basis of this framework of competencies represents both a necessity and a challenge for the educational systems of the Western Hemisphere. It is a challenge since it is an immense academic task based upon a complex theme. It is a necessity because a central task of defining and channeling the educational systems of the nations of the Americas is a responsibility hopefully felt by all in the field of educational administration.

\section{NOTES}

1. In this paper we have discussed and expanded the general ideas presented originally by Benno Sander in the following references: Administracão da Educação no Brasil: Evolução do Conhecimento (Fortaleza: Ceará, Edicões UFC, 1982); “Administracao da Educação no Brasil: É Hora da Relevancia," in Educação Brasileira (Brasilia: 
Ano IV, no. 9, 2 semestre de 1982), pp. 08-27; “Administración de la Educación en America Latina: El Concepto de Relevancia Cultural," La Educación(Washington, D.C.: Organización de los Estados Americanos, no. 94, 1984); and "Educational Administration in Latin America and the Caribbean: In Pursuit of New Paradigms," in Proceedings of the Workshop on Microcomputers and Educational Planning and Administration (Port of Spain, 1983), pp. 01-03.

2. F. W. Taylor, Principles of Scientific Management (New York: Harper and Row, 1911); H. Fayol, Administration Industrielle et Generale (Paris: Dunod, 1916); and M. Weber, The Theory of Social and Economic Organization (New York: The Free Press, 1964).

3. E. Mayo, The Human Problems of an Industrial Civilization (New York: Macmillan, 1933); F. J. Roethlisberger and W. J. Dickson, Management and the Worker (Cambridge: Harvard University Press, 1939); C. I. Barnard, The Functions of the Executive (Cambridge: Harvard University Press, 1938); and H. A. Simon, Administrative Behavior (New York: Macmillan, 1945).

4. W. G. Bennis, Desenvolvimento Organizacional: Sua Natureza, Origens e Perspectivas (São Paulo: Edgard Blucher, 1972); F. Heady, Public Administration: A Comparative Perspective (New York: Marcel Dekker, 1979); F. W. Riggs, Administração nos Países em Desenvolvimento: Teoria da Sociedade Prismática (RJ: Fundação Getúlio Vargas, 1968); M. J. Esman, and H. C. Blaise, Institution Building Research: The Guiding Concepts (Pittsburgh: The University of Pittsburgh Graduate School of Public and International Affairs, 1966); P. R. Lawrence and J. W. Lorsch, As Empresas e o Ambiente: Diferenciação e Integração Administrativas (Petrópolis: Vozes, 1973); P. F. Drucker, Management (New York: Harper, 1977); and Idem, The Effective Executive (London: Heinemann, 1967).

5. Statements on these efforts can be found in the following works: M. Crozier and E. Friedberg, L'Acteur et le Systeme: les Constraintes de l'Action Collective (Paris: Ed. du Seuil, 1977); A. Touraine, Sociologie de l'Action (Paris: Ed. du Seuil, 1965); J. Culbertson, "Three Epistemologies and the Study of Educational Administration", UCEA Review 22, 1 (1981): 1-6; T. B. Greenfield, "Theory about Organizations", in Administering Education: International Challenge, M. Hughes, ed. (London: The Athlone Press, 1975); G. Burrell and G. Morgan, Sociological Paradigms and Organizational Analysis (London: Heineman, 1980); R. J. Bates, "Toward a Critical Practice of Educational Administration" (American Educational Research Association, New York, 1982), (Mimeo); A. G. Ramos, A Nova Ciências das Organizacoes (RJ: Fundacao Getúlio Vargas, 1981).

6. An analysis of the evolution of the theory of administration of Brazilian education in the context of the history of knowledge of public administration is found in: B. Sander, Administração da Educação no Brasil: Evolução do Conhecimento (Fortaleza/Brasilia: Ed. UFC/ANPAE, 1982), pp. 11-30.

7. See, for example, the Brazilian translation of the book by C. I. Barnard, As Funções do Executivo (SP: Atlas, 1971).

8. F. W. Taylor, Principles of Scientific Management (New York: Harper and Row, 1961); H. Emerson, The Twelve Principles of Efficiency (New York: Engineering Magazine, 1913); and R. E. Callahan, Education and the Cult of Efficiency (Chicago: The University of Chicago Press, 1962).

9. C. I. Barnard, As Funções do Executivo (SP: Atlas, 1971); H. A. Simon, Administrative Behaviour(New York: Macmillan, 1945); and J. A. Getzels, J. L. Lipham, and R. F. Campbell, Educational Administration as a Social Process (New York: Harper and Row, 1968). 
10. American Heritage Dictionary (Boston: Houghton Mifflin, 1975), p. 416.

11. H. Emerson, The Twelve Principles of Efficiency (New York: Engineering, 1913).

12. H. Emerson, Efficiency as a Basis for Operations and Wages (New York: Engineering, 1911), p. 37.

13. See H. Munsterberg, Psychology and Industrial Engineering (Boston: Houghton Mifflin, 1913).

14. P. F. Drucker, Practice of Management (New York: Harper and Row, 1954); G. S. Odiorne, Management by Objectives (New York: Pitman, 1965); and J. W. Humble, Management by Objectives (London: Industrial Education and Research Foundation, 1967).

15. C. I. Barnard, The Functions of the Executive (Cambridge: Harvard University Press, 1938), p. 44.

16. See: WEBSTER's New World Dictionary (New York: The World Publishing Company, 1970), p. 445; and American Heritage Dictionary (Boston: Houghton Mifflin, 1975), p. 416.

17. Accountability is a conceptual extension of the classical school. It is translated in terms of responsibility and administrative reliability in an attempt to relate the classical principles of efficiency and precision in the utilization of resources with substantive measurable results. See L. J. Browder, ed., Emerging Patterns of Accountability (Berkeley: McCutchan, 1971).

18. P. R. Motta, “Administração para o Desenvolvimento: a Disciplina em Busca de Relevancia,” Rev. de Administração Pública 6, 3 (July/Sept. 1972): 42.

19. For a recent discussion of the concept of solidarity in education see: J. C. Marques, “Administração Solidária: Proposta ou Desafio," Revista Brasileira de Administração da Educaçào 1, 1 (Jan./June 1983); 79-88.

20. See, for example: L. C. Wittman, "Habilitação em Administração da Educação: Pressupostos e Perspectivas," Informativo ANPAE 3 (July/Sept. 1981): 7-9.

21. K. E. Weick, "Educational Organizations as Loosely Coupled Systems," Administrative Science Quarterly 21 (1976): 1-19.

22. The relationship between these constructs is addressed by Weick, "Educational Organizations"; and J. Pfeffer and G. R. Salancik, The External Control of Organizations (New York: Harper and Row Publishers, 1978).

23. W. R. Scott, Organizations (Englewood Cliffs: Prentice-Hall, 1981), p. 14.

24. WEBSTER's Seventh New Collegiate Dictionary (Springfield: Merriam, 1965), p. 723.

25. A recent discussion of the concept of relevance in public administration is found in P. R. Vieira and A. M. Campos, "Em busca de uma metodologia de pesquisa relevante para a administração pública,” Rev. de Administração Pública 16, 3 (July/Sept. 1980): 101-110.

26. Wittmann, “Habilitação em Administração," pp. 7-9.

27. Ibid., pp. 7-9.

28. J. H. M. Brito, “Administração Universitária: Alternativa Empresarial ou Acadêmica," Informativo ANPAE 3 (1980): 5-8.

29. M. Gonzalez Arroyo, "Administração da Educação, Poder e Participação," Educaçào e Sociedade 2 (Jan. 1979): 34-36; and Wittmann, "Habilitação em Administraçào," pp. 7-9.

30. A. M. Rezende, J. C. Santos Filho, and L. R. Carvalho, "Administraçào Universitária como Ato Pedagogico,” Educaçào Brasileira 1, 12 (1978): 15-58; A. M. Rezende, “Administrar é Educar ou Deseducar?” Educaçào e Sociedade 1, 2 (1979): 25-35; 
and Idem, “Administração Universitária: Alternativa Empresarial ou Acadêmica," Informativo ANPAE 1 (1980): 6-8.

31. This perspective is founded on the concepts of Kuhn and Popper on the elaboration of scientific knowledge. See T. S. Kuhn, The Structure of Scientific Revolutions (Chicago: University of Chicago Press, 1980); and K. R. Popper, Conjectures and Refutations (New York: Basic Books, 1962).

32. On the concept of responsible freedom, see E. Mounier, El Personalismo (Lisbon: Moraes, 1970).

33. This paper brings together various elements found in modern social science, particularly in the work of Alberto Guerreiro Ramos, published in A Nova Ciência das Organizaçòes: uma Reconceituacao da Riqueza das Nacoes (RJ: Fundacao Getulio Vargas, 1981). In this work, Guerreiro Ramos presents a lucid critical analysis of social science and of organizational theory of the 20th century centered on "market logic." $\mathrm{He}$ counters it with the conceptual framework of a new science of organizations which he makes operational in his "paraeconomic paradigm." As a matter of fact, the "paraeconomic paradigm" is a new multicentric model of analysis and planning in social systems. The work of Guerreiro Ramos makes it possible to draw valuable conceptual derivations for the definition of the educational system and the study of its administration. University Press, 1964).

35. "INVESTMENT in Human Beings," Supplement of the Journal of Political Economy, Part II 70, 5 (Oct. 1962).

36. See, for example: E. Rattner, Planejamento e Bem-Estar Social (SP: Perspectivas, 1979), pp. 125-164; F. H. Cardoso, “Aspectos Políticos do Planejamento,"in B. M. Lafer, Planejamento no Brasil(SP: Perspectiva, 1975), pp. 161-184; D. A. Gusso, "Planejamento Educacional: Aspectos Básicos de uma Transição de Métodos e Conceítos," Subsidios ao Planejamento Participativo (Brasilia: MEC/SG, 1980), pp. 101-117; J. R. Velloso, Educational Planning and Decision-Making Models in Brazil (New York: UNESCO, 1978); A. M. Campos, "Um Novo Modelo de Planejamento para uma Nova. Estratégia de Desenvolvimento," Rev. de Administracao Públiçã 14, 3 (July/Sept. 1980), pp.27-45; C. Pallan Figueroa, "La Administración y la Planeación de la Educación Superior Frente al Requerimento del Desarrollo Social." in Planeación de la Educación Superior (Mexico: ANUIES/Sept. 1981); M. Carnoy, Education as Cultural Imperialism (New York: McKay, 1974); and C. Jencks, Inequality: a Reassessment of the Effect of Family and Schooling in America (New York: Basic Books, 1972).

37. See: A. M. Rezende, J. C. Santos Filho, and L. R. Carvalho, “Administraçáo da Educaçáo como Ato Pedagogico,” Educaçáo Brasileira 1, 12 (1978): 15-58.

38. V. Chagas, Educaçáo Brasileira: o Ensino de 10 e 20 Graus (São Paulo: Edicoes Saraiva, 1978), p. 303.

39. The multidimensional paradigm has been recently tested empirically in Brazil by Ana Elizabeth L.A. dos Santos, “O Processo Decisório no MEC: Un Jogo de Forças na Administração da Educação” (M.A. thesis, University of Brasilia, 1984). 